\title{
Serum levels of YKL-40 and C reactive protein in patients with hip osteoarthritis and healthy subjects: a cross sectional study
} Th Conrozier, M-C Carlier, P Mathieu, F Colson, A L Debard, S Richard, H Favret,
J Bienvenu, E Vignon rial chitinase protein family, but YKL-40 function is unknown. One can speculate that it acts as a glycosidic bond hydrolase and plays a part in the tissue remodelling process. $^{2}$ A number of studies have suggested that YKL-40 may be a surrogate marker for inflammatory and degenerative joint diseases. ${ }^{15-7}$ It has been established that YKL-40 is produced in large amounts by activated macrophages, ${ }^{8}$ but its expression is detectable only at a late stage of macrophage maturation. ${ }^{9}$

YKL-40 mRNA is detectable in macrophages from rheumatoid synovium, ${ }^{10}$ and in cartilage of patients with rheumatoid arthritis (RA), but not in healthy subjects. ${ }^{2}$ Immunohistological analysis shows that YKL-40 is found in chondrocytes of osteoarthritic cartilage, with a preferential distribution in the superficial and middle layers and in the loading zone. ${ }^{11}$ Radioimmunoassay shows that YKL-40 serum levels are higher in patients with active RA and osteoarthritis (OA) than in healthy controls and patients with inactive RA. ${ }^{15-7}$ Synovial fluid (SF) concentrations are 10- to 15-fold higher than serum concentrations and decrease after treatment with prednisolone in patients with RA. ${ }^{17}$ SF and serum YKL-40 levels are correlated, suggesting a local production of the protein by the joint. ${ }^{157}$ So it is tempting to speculate that YKL-40 may be a marker of synovial inflammation in OA and RA.

$C$ reactive protein (CRP) which is one of the most useful markers of systemic inflammation has been shown to be correlated with serum YKL-40 in RA. ${ }^{6}$ Recent studies have underlined interest in the presence of CRP in OA. ${ }^{12-14}$ Indeed CRP has been shown to be slightly but significantly higher in patients with OA than in matched controls. ${ }^{12}$ Furthermore, CRP was found to increase in patients with knee OA showing disease progression ${ }^{12}$ and in patients with rapidly destructive hip OA. ${ }^{13}$ In addition, C reactive protein but not erythrocyte sedimentation rate was shown to be associated with clinical severity in patients with OA of the knee or hip. ${ }^{14} \mathrm{~A}$ correlation between YKL-40 and CRP has not been yet shown in hip OA. Our study aimed at investigating the serum concentration of YKL-40 in patients with OA of the hip and its relation with CRP. cartilage human chondrocytes, ${ }^{12}$ synovial fibroblasts, ${ }^{3}$ and the osteosarcoma cell line MG-63, ${ }^{4}$ but not by lung and skin fibroblasts. ${ }^{3}$ Its name comes from the one letter code for its first three $\mathrm{N}$-terminal amino acids and from its molecular weight of $40 \mathrm{kDa} .{ }^{4}$ It has also been called HC gp $-39^{2}$ and chondrex. ${ }^{5}$ The amino acid sequence shows homology with the bacte-
Patients and methods

PATIENTS AND CLINICAL DATA

This cross sectional study was conducted in 45 patients (24 women, 21 men, mean age 65) referred to the department of rheumatology for 
symptomatic hip OA (median disease duration 48 months, range 9-120) and who fulfilled the ACR criteria for hip OA. ${ }^{15}$ Hip OA secondary to alternative arthropathies was excluded (that is, infectious or inflammatory arthritis, hip injury, aseptic osteonecrosis, and congenital abnormality, such as congenital dislocation of the hip). Patients were receiving various drugs, including analgesics and non-steroidal antiinflammatory drugs (NSAIDs), but none of them had received any intra-articular steroidal injections for at least three months before the start of the study. None presented clinically detectable disease that might have interfered with the current level of YKL-40 and CRP. For each patient, all clinical, laboratory, and radiological data were obtained on the same day.

RADIOLOGICAL DATA

All patients underwent radiography of the pelvis, performed by the same radiologist, using a standardised radiological procedure. Anteroposterior radiographs of the pelvis were obtained with the patient in a standing position with $20^{\circ}$ of internal rotation of the legs. The focus-film distance was $100 \mathrm{~cm}$ and the beam was aligned with the top of the pubic symphysis.

Both joint space area and the interbone distance at the narrowest point (minimal joint space width (JSW)) were determined with the help of a digitised image analysis computer using specific software (HLS Actibase, Lyon, France), as described previously. ${ }^{16-18}$ The joint space contours were delineated with the mouse on the following margins: the superior convex edge of the femoral head and the inferior margin of the acetabulum to obtain the joint space surface area (JSA) and the mean JSW. The minimum JSW was automatically calculated by the computer by screening the joint space every $0.5 \mathrm{~mm}$. The intraobserver coefficient of variation (CV) for repeated measurements of the same film was $1.2 \%$.

BIOLOGICAL DATA

Blood samples were obtained from each subject on the day the radiographs were taken. The serum was immediately frozen and stored at $-35^{\circ} \mathrm{C}$. Serum YKL-40 was assayed on the same day by a sandwich immunoassay in a microtitre stripwell format (Chondrex, Metra Biosystems, Inc, USA). The Fab fragment of a monoclonal anti-YKL-40 antibody conjugated to biotin binds to streptavidin on the strip and captures YKL-40. A conjugated polyclonal anti-YKL-40 antibody conjugated with alkaline phosphatase binds to the captured YKL40. Bound enzyme activity is detected with p-nitrophenyl phosphate as substrate. The intra-assay $\mathrm{CV}$ was less than $7 \%$.

$\mathrm{C}$ reactive protein was assayed by immunonephelometry (N Latex CRP mono, Behringwerke AG, Germany) using a nephelometer BNA Behring. When the serum is diluted $1 / 400$ the assay detects CRP concentrations in the range $3.5-220 \mathrm{mg} / 1$. A $1 / 20$ dilution was also used to ensure detection of levels between 0.175 and $11 \mathrm{mg} / \mathrm{l}$. The intra-assay $\mathrm{CV}$ was calculated using serum samples from 10 patients admitted for sciatica in whom the CRP level was less than $5 \mathrm{mg} / \mathrm{l}$. Each of the $10 \mathrm{sam}-$ ples was tested three times. The mean intra-assay CV was $4.75 \%$ (range $0.5-11 \%$ ) for a mean (SD) CRP level of $2.44(2.66) \mathrm{mg} /$. $^{13}$

The normal serum values of YKL-40 and CRP were given by blood sampling in 33 volunteers (mean age 42, range 32-49). None of the controls presented symptomatic OA, or clinically detectable inflammatory or infectious disease.

\section{STATISTICAL ANALYSIS}

To investigate correlations between continuous variables linear regression was used. When the distribution of the values was not normal, log transformed data were used for correlation studies and the Mann-Whitney U test was performed for between-group comparisons.

Between-group comparisons of the other variables were made using Student's $t$ test. Factors found to be associated in a univariate analysis were then studied in a multiple regression analysis. Adjustment for potentially confounding factors was performed by analysis of variance. Values $\mathrm{p}<0.05$ were considered significant.

\section{Results}

Table 1 summarises the radiographic and biological characteristics of the patients. The mean (standard error) YKL-40 level was 90.3 (8.2) $\mathrm{ng} / \mathrm{ml}$ in patients with hip $\mathrm{OA}$ and 66.9 (8.2) $\mathrm{ng} / \mathrm{ml}$ in controls. The difference was significant $(p=0.03)$ (fig 1$)$. Three patients (two with OA, one control) were excluded from the analysis; they had a CRP level $>20 \mathrm{mg} / 1$ not attributable to OA $(21,40.5$, and $24.8 \mathrm{mg} / \mathrm{l})$, probably due to a non-clinically evident infectious disease. In these patients YKL-40 was 56 , 192 , and $70 \mathrm{ng} / \mathrm{ml}$ respectively).

The mean CRP level was 2.93 (3.03) mg/l and $1.40(1.61) \mathrm{mg} / \mathrm{l}$ in $\mathrm{OA}$ and controls respectively $(p=0.006)$ (fig 2$)$. The difference between $\mathrm{OA}$ and controls remained significant even when the three patients mentioned above were analysed $(p=0.007)$.

Table 1 Biological and radiographic characteristics of patients and controls. (Statistics: Mann-Whitney U test)

\begin{tabular}{|c|c|c|c|c|c|c|c|}
\hline \multirow[b]{2}{*}{ Subjects } & \multicolumn{3}{|c|}{ Osteoarthritis $(n=45)$} & \multicolumn{3}{|c|}{ Controls $(n=33)$} & \multirow[b]{2}{*}{$p$ Value $^{\star}$} \\
\hline & Mean & Median & Range & Mean & Median & Range & \\
\hline YKL-40 (ng/ml) & 90.3 & 67.5 & $33-343$ & 66.93 & 59.0 & $20-262$ & 0.035 \\
\hline $\mathrm{C}$ reactive protein $(\mathrm{mg} / \mathrm{l})$ & 2.93 & 2.03 & $0.17-9.3$ & 1.40 & 0.93 & $0.17-7.84$ & 0.006 \\
\hline Age (years) & 65 & 68 & $30-84$ & 42 & 46 & $32-50$ & 0.001 \\
\hline Mean joint space width (mm) & 1.7 & 1.6 & $3.8-0$ & ND & ND & ND & \\
\hline Minimum joint space width (mm) & 1.3 & 1.1 & $3.6-0$ & ND & ND & ND & \\
\hline
\end{tabular}

$\star \mathrm{p}$ Value-osteoarthritis $v$ controls.

$\mathrm{ND}=$ not done 


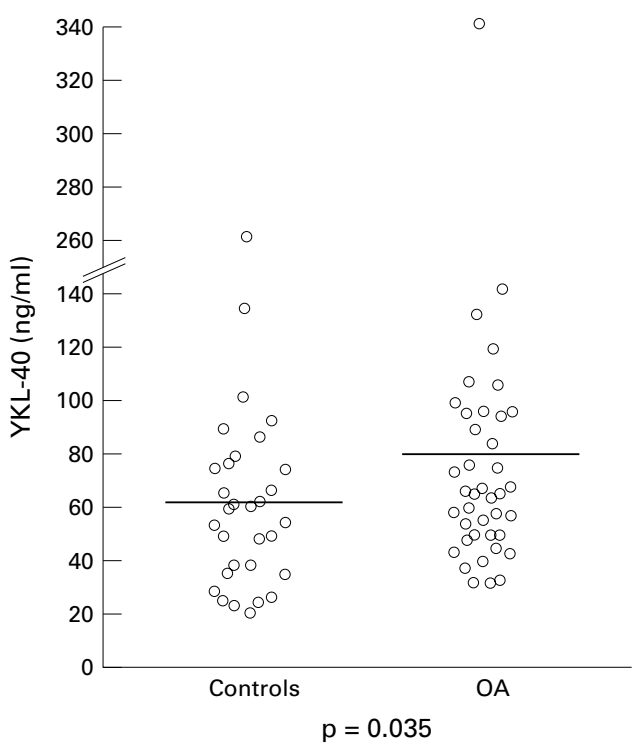

Figure 1 Comparison of YKL-40 serum levels in 45 patients with hip osteoarthritis $(O A)$ and 33 healthy controls (Mann-Whitney $U$ test, $p=0.035$ ).

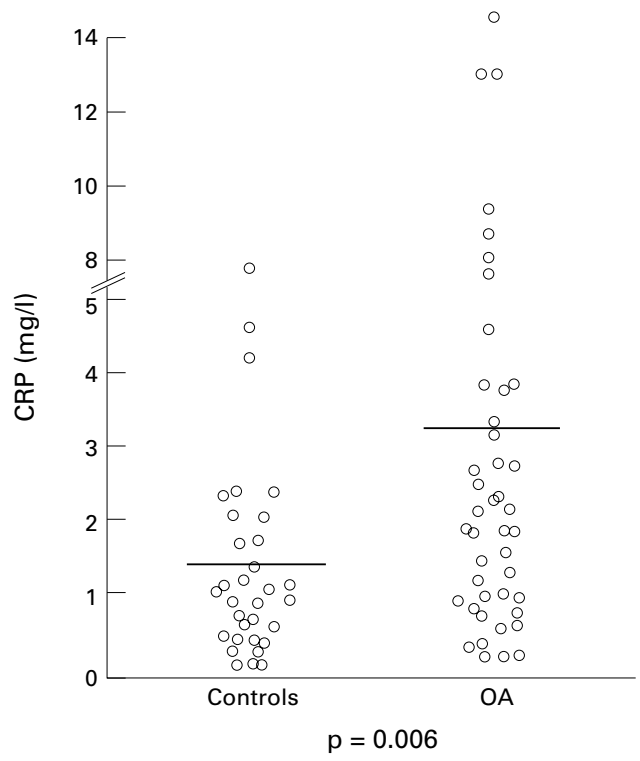

Figure 2 Comparison of $C$ reactive protein (CRP) serum levels in 43 patients with hip osteoarthritis $(O A)$ and 32 healthy controls (Mann-Whitney $U$ test, $p=0.006$ ).

Neither YKL-40 nor CRP differed significantly between men and women $(\mathrm{p}=0.06$ and $\mathrm{p}=0.42$, respectively).

In patients with OA YKL-40 and CRP serum levels correlated significantly (Spearman test: $\left.r_{\mathrm{s}}=0.39, \mathrm{p}=0.01\right)$. Such a correlation was not found in controls $(p=0.94)$. YKL-40 and CRP levels showed a non-normal distribution so that logarithms of their values were used for the regression curve $\left(r_{\mathrm{s}}=0.42, \mathrm{p}=0.005\right)$ (fig $3)$. Both YKL-40 and CRP correlated with age $\left(r_{\mathrm{s}}=0.38\right.$ and 0.41 respectively, $\left.\mathrm{p}=0.01\right)$. After adjustment for age YLK-40 and CRP remained correlated $(\mathrm{p}=0.04)$.

In contrast, radiological joint space width (JSA and mean JSW as well as minimum JSW) and disease duration were unrelated to YKL-40 and CRP.

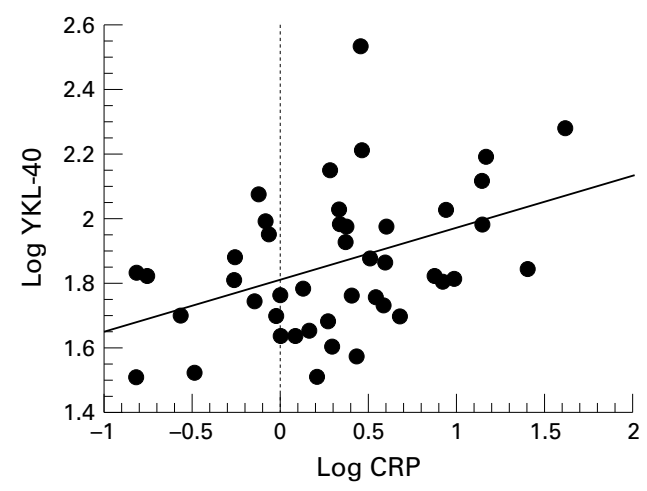

Figure 3 Correlation between serum concentrations of YKL-40 and $C$ reactive protein $\left(C R P ; r_{s}=0.42, p=0.005\right)$ in 45 patients with osteoarthritis of the hip (log transformed data).

\section{Discussion}

This study confirms previous data showing that both YKL-40 and CRP are increased in serum of patients with OA. ${ }^{78}$ Our study group comprised patients with symptomatic and advanced hip OA, as shown by the median of the minimum JSW of $1.1 \mathrm{~mm}$. Our results show that patients with hip OA had serum levels of YKL-40 36\% higher than those of controls, but part of this difference might have been due to the difference in age of the patients and controls. Indeed, we showed a weak positive correlation between YKL-40 serum concentration and age, as found by Cintin et al. ${ }^{19}$ Johansen et al reported that serum YKL-40 increased in healthy subjects older than 70 years, ${ }^{7}$ while Harvey et al reported a slight decrease with age in women but not in men. ${ }^{5}$ However, the present data corroborate those from other studies, in which CRP concentrations were shown to be significantly higher in patients with hip and knee OA than in controls. ${ }^{12-14}$ Furthermore, CRP concentrations (median $2.03 \mathrm{mg} / \mathrm{l}$ ) are closely similar to those obtained by immunoassay ${ }^{12}$ or nephelometry ${ }^{13}$ in both knee and hip OA. The positive correlation between the YKL-40 and CRP serum concentrations is the main finding in this study. Such a correlation was previously reported for patients with RA and the correlation coefficient was similar in $\mathrm{OA}$ to the one reported in patients with RA (Spearman's $r_{\mathrm{s}}=0.39$ and 0.40 respectively). ${ }^{6}$ This weak but significant correlation suggests that CRP and YKL-40 reflect two different aspects of the inflammatory process in joint diseases. CRP is a pentameric protein of the lectin family produced by the liver under the influence of various cytokines. In arthritis CRP production reflects the release in the affected joints of proinflammatory cytokines, such as interleukins 1 and 6 and tumour necrosis factor $\alpha$, which play a part in the mechanism of cartilage destruction. Tenidap, a new NSAID, which inhibits both interleukin 1 and interleukin 6 production, ${ }^{20}{ }^{21}$ reduces CRP serum levels in patients with RA and OA. ${ }^{22}{ }^{23}$ On the contrary, YKL-40 is not secreted by hepatocytes. ${ }^{24}$ Its local production by joints is suggested by the finding of a 10-fold higher concentration in SF than in serum, as well as a positive correlation between them. YKL-40 is produced by articu- 
lar chondrocytes, synovial cell neutrophils, and macrophages. ${ }^{8-10} 25$ The present data do not indicate which of these cells is the main source of the increased serum concentrations of YKL-40 in OA. The lack of a relation between JSW and YKL-40 suggests that articular chondrocytes are not the major source of the marker. It is tempting to speculate that YKL-40 may be a marker of the low grade synovitis of the osteoarthritic process at a given time, whereas joint space narrowing in the $x$ ray film represents the irreversible damage resulting from the disease process. Its clinical relevance for assessing substantial overlap between YKL-40 levels in patients with OA and controls suggests that YKL-40 may be of limited value for evaluating an individual patient. Furthermore, high serum levels of YKL-40 were reported in various diseases, such as giant cell arteritis, ${ }^{24}$ colorectal and breast cancer, in which it was associated with short survival. ${ }^{19}$ High amounts of YKL-40 in apparently healthy subjects (that is, three of our controls) suggest the possibility of cancer or liver fibrosis. ${ }^{1925}$

In summary, our study indicates that in patients with symptomatic hip OA the serum concentrations of YKL-40 are increased and correlate with CRP. Further longitudinal studies are necessary to assess the value of YKL-40 for monitoring patients with OA, and its possible use in monitoring clinical response to NSAIDs and disease modifying OA drugs.

1 Johansen JS, Jensen HS, Price PA. A new biochemical marker for joint injury. Analysis of YKL-40 in serum and marker for joint injury. Analysis of YKL-40 in ser

2 Hakala BE, White C, Recklies AD. Human cartilage gp-39, a major secretory product of articular chondrocytes and a major secretory product of articular chondrocytes and synovial cells, is a mammalian member of

3 Nyirkos P, Golds EE. Human synovial cells secrete a $39 \mathrm{kD}$ protein similar to a bovine mammary protein expressed during the non-lactating period. Biochem J 1993;268: 265-8

4 Johansen JS, Williamson MK, Rice JS, Price PA. Identification of proteins secreted by human osteoblastic cells in culture. J Bone Miner Res 1992;7:501-12 .

5 Harvey S, Weisman M, O'Dell J, Scott T, Krusemeier M, Wisor J, et al. Chondrex: new marker of joint disease. Clin Chem 1998;44:509-16.

6 Johansen JS, Stoltenberg M, Hansen M, Florescu K, Horslev-Petersen I, Lorenzen I, et al. Serum YKL-40 concentrations in patients with rheumatoid arthritis: relation to disease activity. Rheumatology 1999;38:618-26.

7 Johansen JS, Hvolris J, Hansen M, Backer V, Lorenzen I,

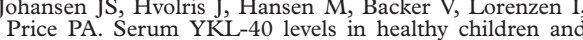
Price PA. Serum YKL-40 levels in healthy children and YKL-40 in patients with osteoarthritis or trauma of the knee joint. Br J Rheumatol 1996;35:533-9.
8 Renkema GH, Boot RG, Au FL, Donker-Koopman WE, Strijland A, Muijsers AO, et al. Chitotriosidase, a chitinase, and the $39-\mathrm{kDa}$ human cartilage glycoprotein, a chitinbinding lectin, are homologues of family 18 glycosyl hydrobinding lectin, are homologues of family 18 glycosyl hydrolases secreted by

1998;251:504-9.
9 Krause SW, Rehli M, Kreutz M, Schwarzfischer L, Paulauskis JD, Andreesen R. Differential screening identifies genetic markers of monocyte to macrophage maturation. J Leukoc Biol 1996;60:540-5.

10 Kirkpatrick RB, Emery JG, Connor JR, Dodds R, Lysko PG, Rosenberg M. Induction and expression of human cartilage glycoprotein 39 in rheumatoid inflammatory and peripheral blood monocytes-derived macrophages. Exp Cell Res 1997;237:46-54.

11 Volk B, Ostergaard K, Johansen JS, Garbarsch C, Price PA The distribution of YKL-40 in osteoarthritic and normal human articular cartilage. Scand J Rheumatol 1999;28: human

12 Spector TD, Hart DJ, Nandra D, Doyle DV, Mackillop N, Gallimore JR, et al. Low-level increases in serum C reactive protein are present in early osteoarthritis of the knee and predict progressive disease. Arthritis Rheum 1997;40: 723-7

13 Conrozier T, Chapuis-Cellier C, Richard M, Mathieu P, Richard S,Vignon E. Increased serum-C-reactive protein levels by immunonephelometry in patients with rapidly destructive osteoarthritis. Rev Rhum Engl Ed 1998;65: $759-65$

14 Wolfe $\mathrm{F}$. The $\mathrm{C}$ reactive protein but not erythrocyte sedimentation rate is associated with clinical severity in patients with osteoarthritis of the knee or hip. J Rheumatol 1997;24:1486-8.

15 Altman R, Alarcon D, Appelrouth D and the American College of Rheumatology subcommittee on criteria for osteoarthritis. The American College of Rheumatology criteria for the classification and reporting of osteoarthritis of teria for the classification and reporting of o

16 Conrozier T, Tron AM, Mathieu P, Vignon E. Quantitative assessment of radiographic normal and osteoarthritic hip joint space. Osteoarthritis Cartilage 1995;3(suppl A):81-7.

17 Conrozier T, Jousseaume CA, Mathieu P, Tron AM, Caton $\mathrm{J}$, Bejui J, et al. Quantitative measurement of the joint space narrowing progression in hip osteoarthritis. A longitudinal retrospective study of patients treated by total hip arthroplasty. Br J Rheumatol 1998;17:961-8

18 Conrozier T, Saxne T, Shan Sei Fan C, Mathieu P, Tron AM, Heinegard D, et al. Serum concentrations of cartilage oligomeric matrix protein and bone sialoprotein in hip osteoarthritis: a one year prospective study. Ann Rheum Dis 1998;57:527-32.

19 Cintin C, Johansen JS, Christensen IJ, Price PA, Sorensen S, Nielsen HJ. Serum YKL-40 and colorectal cancer. Br J Cancer 1999;79:1494-9.

20 Otterness IG, Bliven ML, Downs JT, Natoli EJ, Hanson DC. Inhibition of interleukin 1 synthesis by tenidap: a new DC. Inhibition of interleukin 1 synthesis by
drug for arthritis. Cytokine 1991;3:227-83.

21 Sipe JD, Bartle MN, Loose LD. Modification of the proinflammatory cytokine production by the antirheumatic agents tenidap and naproxen. J Immunol 1992;148:480-4.

22 Loose LD, de Oliveira R, Sipe JD, Franzblau C, Shanahan WR. A possible systemic component of osteoarthritis: elevated concentrations (by ELISA) of C reactive protein in serum of $\mathrm{OA}$ patients and modulation by tenidap [abstract]. Arthritis Rheum 1996;39(suppl):S166.

23 Loose LD, Sipe JD, Kirby DS, Kraska AR, Weiner ES, Shanahan WR, et al. Reduction of acute-phase proteins with tenidap, a cytokine modulating antirheumatic drug. $\mathrm{Br}$ J Rheumatol 1993;32(suppl 3):19-25.

24 Johansen JS, Baslund B, Garbasch C, Hansen M, Lorenzen I, Price PA. YKL-40 in giant cells and macrophages from patients with giant cell arteritis. Arthritis Rheum 1999;42: patients with $2624-30$.

25 Johansen JS, Moller S, Price PA, Bendtsen F, Junge J, Garbasch C, et al. Plasma YKL-40: a new potential marker of fibrosis in patients with alcoholic cirrhosis? Scand J Gastroenterol 1997;32:582-90. 